\title{
Mississippi: Conservative Ideologues Battle the Party of Inclusion
}

\author{
James Newman, Stephen D. Shaffer, and David A. Breaux
}

Republican grassroots party activists in Mississippi constitute an essentially conservative, higher income, middle aged, and white male organization, which has become even more so since 1991. Democrats are a truly biracial party with equal numbers of men and women and a more middle class background, but it has become more liberal since 1991 due to the influx of more AfricanAmericans into the organization. Compared to Republicans, Democrats have a more professional orientation geared towards winning elections rather than fighting for ideological purity, and have become increasingly active over the last decade to meet the growing GOP electoral challenge.

\section{Introduction}

As Mississippi enters the 21 st century, the state of party competition is light years removed from the era of one-party Democratic domination described by V.O. Key (1949). Today, a well-organized and generously funded state Republican Party spearheads a GOP effort that has won every presidential election in the Magnolia State since 1980, that controls both of the state's U.S. Senate seats, two of the four U.S. House seats, and has won two of the last four gubernatorial contests. Yet party realignment has been "delayed" in less visible state and local offices, as extensively developed local Democratic parties and ideologically inclusive candidates have contributed to Mississippi remaining one of only three or four southern states where Democrats continue to overwhelmingly control state legislative, nongubernatorial executive offices, and local offices (Shaffer, Pierce, and Kohnke 2000). At this critical juncture when both parties are battling for the hearts and minds of the state's citizenry, it is particularly vital to study the party warriors who make up the two parties' grassroots organizations.

\footnotetext{
JAMES NEWMAN is a PhD student in the Public Policy and Administration program at Mississippi State University. STEPHEN D. SHAFFER is a professor of political science at Mississippi State University. DAVID A. BREAUX is a professor of political science and head of the political science department at Mississippi State University. The authors wish to thank Stacie Berry Pierce for her work as a research assistant on this project.
}

The American Review of Politics, Vol. 24, Spring, 2003: 69-89

(C)2003 The American Review of Politics 


\section{Development of Political Parties in Mississippi}

\section{Modern Electoral Patterns}

Historically a one-party Democratic state, Mississippi today enjoys a competitive two-party system, at least when it comes to contesting the more visible offices (see Table 1). As new generations of voters who no longer remember such seminal events as the Great Depression and the aftermath of the Civil War have entered the electorate, unthinking loyalty to candidates of the once dominant Democratic Party has declined. Instead, the average Mississippian who is basically moderate-to-conservative in philosophy is increasingly willing to vote for candidates of either party who share their basic political values.

Republican electoral gains first emerged at the presidential level, as white Mississippians embraced the conservatism of Barry Goldwater in 1964 and, after a brief detour to back Independent candidate George Wallace four years later, soundly rejected the liberalism of Democratic George McGovern in 1972. Nixon's impressive re-election margins of 76 percent of the vote in the 4th congressional district and 87 percent in the 5th district helped elect Republicans Thad Cochran in the 4th district (housing the state capital of Jackson) and Trent Lott in the 5th district (a more affluent, whiter, Gulf Coast area). Republicans benefited from a racially-split Democratic Party in 1978, when Cochran replaced retiring segregationist Democrat James Eastland in the U.S. Senate. Yet as the decade ended the potential magnitude of GOP gains was unclear, since born-again Southern Baptist Jimmy Carter had narrowly regained Mississippi for the Democrats in 1976 and then barely lost it in the recession-year of 1980.

A reunited and biracial Democratic Party demonstrated its resilience in the last re-election bid of Senator John Stennis in 1982, as he defeated state Republican Party executive director Haley Barbour. In the 1983 gubernatorial contest, Republicans reached a new low as voters rejected their candidate, whose money-backers had proclaimed that Democrat Bill Allain had as attorney general engaged in sex with black male transvestite prostitutes. But in 1984 Cochran became the first post-Reconstruction Republican to win a popular vote majority in a state-wide non-presidential contest by soundly defeating popular former governor William Winter in the U.S. Senate race. Reflecting a new era of intensified two-party politics, Democrats came back two years later with African-American Mike Espy, who unseated a conservative Republican congressman in the racially-polarized 2nd congressional (Mississippi "Delta") district.

The moderate conservative or conservative nature of Republican candidates produced a consistent string of presidential election victories through- 
Table 1. Republican Strength in Mississippi, 1960-2000

\begin{tabular}{|c|c|c|c|c|c|c|c|}
\hline Year & $\begin{array}{l}\text { Percent } \\
\text { Pres. } \\
\text { Vote }\end{array}$ & $\begin{array}{l}\text { Percent } \\
\text { U.S. Senate } \\
\text { Vote }\end{array}$ & $\begin{array}{l}\text { Percent } \\
\text { U.S. House } \\
\text { Delegation }\end{array}$ & $\begin{array}{c}\text { Percent } \\
\text { Gov. } \\
\text { Vote }\end{array}$ & $\begin{array}{l}\text { Percent } \\
\text { Lt. Gov. } \\
\text { Vote }\end{array}$ & $\begin{array}{c}\text { Percent } \\
\text { State House } \\
\text { Delegation }\end{array}$ & $\begin{array}{c}\text { Percent } \\
\text { State Senate } \\
\text { Delegation }\end{array}$ \\
\hline 1960 & 24.7 & 8.2 & 0.0 & & & & \\
\hline 1962 & & & 0.0 & & & & \\
\hline 1963 & & & & 38.1 & 26.0 & 1.6 & 1.9 \\
\hline 1964 & 87.1 & 0.0 & 20.0 & & & & \\
\hline 1966 & & 6.8 & 0.0 & & & & \\
\hline 1967 & & & & 29.7 & 0.0 & 0.0 & 0.0 \\
\hline 1968 & 13.5 & & 0.0 & & & & \\
\hline 1970 & & 0.0 & 0.0 & & & & \\
\hline 1971 & & & & 0.0 & 0.0 & 1.6 & 3.8 \\
\hline 1972 & 78.2 & 38.7 & 40.0 & & & & \\
\hline 1974 & & & 40.0 & & & & \\
\hline 1975 & & & & 45.1 & 30.5 & 2.5 & 3.8 \\
\hline 1976 & 47.7 & 0.0 & 40.0 & & & & \\
\hline 1978 & & $45.1 *$ & 40.0 & & & & \\
\hline 1979 & & & & 38.9 & 0.0 & 3.3 & 7.7 \\
\hline 1980 & $49.4 *$ & & 40.0 & & & & \\
\hline 1982 & & 35.8 & 40.0 & & & & \\
\hline 1983 & & & & 38.9 & 35.7 & 4.9 & 5.8 \\
\hline 1984 & 61.9 & 60.9 & 40.0 & & & & \\
\hline 1986 & & & 20.0 & & & & \\
\hline 1987 & & & & 46.6 & 17.7 & 7.4 & 13.5 \\
\hline 1988 & 59.9 & 53.9 & 20.0 & & & & \\
\hline 1990 & & 100.0 & 0.0 & & & & \\
\hline 1991 & & & & 50.8 & $49.5^{*}$ & 18.9 & 17.3 \\
\hline 1992 & $49.7^{*}$ & & 0.0 & & & 22.1 & 25.0 \\
\hline 1994 & & 68.8 & 20.0 & & & & \\
\hline 1995 & & & $40.0+$ & 55.6 & 47.3 & 27.9 & 34.6 \\
\hline 1996 & $49.9^{*}$ & 71.0 & 60.0 & & & & \\
\hline 1998 & & & 40.0 & & & & \\
\hline 1999 & & & & 48.5 & 47.2 & 27.9 & 34.6 \\
\hline 2000 & 57.6 & 65.9 & 40.0 & & & & \\
\hline
\end{tabular}

Notes: Entries are percentages. The governor and state legislators are elected for four-year terms in the odd numbered year immediately before a presidential election (a special state legislative election was held in 1992 because of redistricting).

*The Republican candidate won with a plurality of the vote in a multi-candidate field.

+The GOP increased its total to 40 percent when 4th District Congressman Mike Parker switched to the Republican Party after the 1995 state elections.

Sources: Shaffer and Breaux 1995:169; Shaffer 2001; Shaffer and Price 2002; Secretary of State of Mississippi 1993, 1997. 
out the last two decades of the 20th century, and some notable gains in other races. In the 1987 gubernatorial race, Republican businessman Jack Reed, a social conservative but member of the state Board of Education and an early civil rights supporter, won a solid 47 percent of the vote against reformminded state auditor Ray Mabus. Four years later, in the midst of a painful recession and after a bitterly divisive Democratic primary, Mabus was narrowly unseated by long-time conservative Republican party activist but publicly unknown businessman Kirk Fordice. Democrat-turned-Republican state senator Eddie Briggs unseated Democratic Lieutenant Governor Brad Dye the same year to become the first Republican lieutenant governor since Reconstruction (Shaffer, Sturrock, Breaux, and Minor 1999).

The GOP's first governor since Reconstruction was then re-elected in 1995, as the blunt-speaking conservative ideologue benefited from a booming economy and television ads that shunned ideology to stress the "Mississippi Miracle." Meanwhile, the Republicans in 1988 picked up the state's second U.S. Senate seat vacated by John Stennis' retirement, as Congressman Trent Lott deftly countered the charge that he was too conservative by outspending Democratic congressman Wayne Dowdy by over a two-to-one margin and running a series of visually-appealing television ads that portrayed Lott as a defender of such popular domestic programs as higher education, social security, and the environment (Shaffer 1991). Republicans were also making gains in the state legislature, as Jack Reed's gubernatorial bid in 1987 helped to double the party's tiny legislative contingent, while Fordice's 1991 victory nearly doubled it once again. With a Republican governor and an energized state GOP party aggressively backing state legislative candidates, the party reached an historic high of occupying nearly onefourth of legislative seats after a special 1992 election necessitated by redistricting (Table 1).

As the state Republican party orchestrated a negative campaign against Democratic legislators in the 1995 state elections in an effort to seize control of the state senate (party switching by early 1995 had increased the GOP share of senate seats to about 35 percent), Democrats fought back by assembling their biracial coalition and painting themselves as a broad-tent party. In the face of a personal victory for Fordice's candidate-centered campaign, Democrats regained the lieutenant governor's office and won every other statewide elected office (though Republicans shortly gained the state auditor's position through gubernatorial appointment after the incumbent's resignation following legal difficulties). Conservative Republicans had blasted Lieutenant Governor Eddie Briggs for not being completely pro-life, and some helped elect Democrat Ronnie Musgrove, a pro-education but socially conservative state senator. Further Republican gains in the legislature leveled out, as voters preferred a broad-tent party that worked to solve 
state problems to a party that seemed to offer only negativism. In the 1999 state elections, Democrats regained even the governorship, as Musgrove's pro-public elementary and secondary education stance trumped Democratturned-Republican congressman Mike Parker's folksy, issueless campaign. Republicans by the turn of the century remained a force to be reckoned with, however, as both of the state's Republican U.S. Senators easily kept winning re-election, the GOP consistently carried Mississippi in presidential elections, and retained two of the state's five (four after the 2000 Census) U.S. House seats. Even at the state level, Republicans since 1991 had never received less than 47 percent of the popular vote for the two top state offices of governor and lieutenant governor. With Lieutenant Governor Amy Tuck's switch to the GOP after the 2002 elections, the Republicans now held two of the eight statewide offices.

\section{The State Party Organizations}

The state Democratic Party today is a truly biracial party, which periodically confronts and overcomes its haunted segregationist tradition. In the 1960s the all-white state Democratic Party had been so resistant to racially integrating its ranks that African-Americans were forced to form their own political party - the Freedom Democrats, and then the "loyalist" Democrats. The loyalists (loyal to the national Democratic Party's presidential candidates) challenged and even unseated the all-white "regular" Democratic delegation to the 1968 and 1972 national Democratic conventions. Prompted by the growing Republican electoral threat and the presidential bid of southern moderate Jimmy Carter, the regulars and loyalists united into the modern Democratic Party, which was initially co-chaired by a white regular and black loyalist.

The biracial state Democratic executive committee legally governs the state party, and its members are independent enough to generally select state party leaders who seek to maintain racial harmony and to promote the electoral hopes of the party more generally, rather than to merely promote their governor's interests. While Democrats followed Governor Winter's advice in 1980 to attract white voters by ending the dual chairmanship in favor of a white male campaign supporter of his, the new chair was a former Loyalist, and in 1981 an African-American who had been a staff aide to Senators Stennis and Eastland, Ed Cole, was elected vice-chair. In 1984 the state committee also endorsed Governor Bill Allain's choice of a white campaign supporter for state party chair, but the chair's resignation in 1987 led the committee to unanimously elevate vice chair Ed Cole to the top spot (Breaux, Shaffer, and Wilson 1997).

The uneasy alliance between whites and blacks within the state Democratic Party was sorely tested in 1988 after newly elected Governor Ray 
Mabus sought to replace Cole with a white female campaign supporter of his. After an emotional meeting where Cole supporters invoked the memory of Martin Luther King, the state executive committee rebuffed the governor and retained Cole as state party chair. Cole was then succeeded in 1994 by another African-American, state senator Johnnie Walls.

Racial tensions reemerged at the 1996 state party convention, as Democrats re-elected African-Americans Johnny Walls as chair and state senator Alice Harden to the DNC, but proceeded to replace a white male DNC member, who had reportedly angered African-American Congressman Bennie Thompson, with a black male. Countering the claim that it was now an "allblack party," state Democrats elevated the white male challenger in the chairmanship election to the post of executive vice-chairman. In the succeeding years, a liberal white male, Rickey Cole, was elected to one of the two DNC positions, and a liberal white female was elected state party chair. After Musgrove's election as governor in 1999, his choice of a white male businessman, Jon Levingston was elected chair. After Levingston's resignation, the state committee elected Rickey Cole, a fifteen-year state executive committee member, former Young Democrats chairman, and chair of the county chairs association, as state party chair.

The state Democratic Party organization is led by the chairman, and is generally assisted by a full-time executive director and at least one staff assistant or secretary, but financial problems have plagued the party. There was a three-year vacancy in the executive directorship and frequent closings of the state party headquarters in the early 1990s, and allegations that as late as 2000 the party was unable to fully pay the state executive director's promised salary. The state party's major fund-raising events include the annual Jefferson-Jackson Day dinner, highlighted by a national party figure and attended by Democratic elected officials, and a small donors program referred to as the Yellow Dog Democrats.

Democrats are the stronger party at the county level, since under state law they must conduct party primaries and certify the nomination of candidates. An example of an effective county committee is in Oktibbeha, the home of the state's largest university, Mississippi State University. An annual Beans and Greens dinner is highlighted by speakers that have recently included Governor Musgrove and Agriculture Commissioner Lester Spell, and that is typically attended by five hundred people including numerous elected officials. The county party distributes a newsletter four times a year, and in 2001 publicly urged voters to change the state flag to remove the Confederacy design. Democratic Party superiority in organization at the county and local levels has helped preserve the party's dominance in these lower level elections. Even after the most recent 1999 state elections, only seven of the state's 82 county sheriffs were Republican, as were only 48 of the 410 county supervisors (Shaffer 2001). 
The state Republican Party, unaffected by racial tensions given its nearly lily-white composition, instead sometimes finds itself torn between its "purist" conservative and "pragmatic" conservative wings. Historically drawing on the financial and manpower resources of purist conservatives who have backed such ideologues as Barry Goldwater in the early 1960s and Ronald Reagan in the 1980s, the state party generally selects as its chairmen pragmatic conservatives who have sought to create a broader tent Republican Party that includes African-Americans and party-switching Democrats who agree with Republican principles. Clarke Reed led the party in the 1960s and 1970s, rising to chair the Southern Republican State Chairmen's Association, and backed moderate conservative Gerald Ford in the 1976 GOP presidential nomination cliffhanger over purist conservative Ronald Reagan. From 1982 through 1993, two dynamic women aggressively served as state party "chairman," Ebbie Spivey and Evelyn McPhail. Businessman Mike Retzer served twice as party chairman, during Thad Cochran's initial election as Senator and in the late 1990s (Breaux, Shaffer, and Wilson 1997). Most recently, former Democrat Jim Herring, who became state chairman in 2001, has publicly proclaimed the GOP conservative philosophy of limited government and individual self-reliance, blasted the Democratic governor and state legislature for their failure to work together, and attacked legislative Democrats who backed a congressional redistricting plan that benefitted their party (a federal court imposed a more "Republican" plan).

The state Republican Party is clearly better funded than the Democrats, permitting a sizable staff of as many as ten people, four of whom in 2002 were women and one an African American. This paid staff over the past twenty years has typically included an executive director, directors of finance and communications, and a political consultant, and by 2002 also included an information systems director and a webmaster who also oversaw redistricting controversies. Republicans have a computerized list of party activists and contributors, and an effective telemarketing fund-raising operation. Their frequent state fund-raising dinners are highlighted by such luminaries as Republican U.S. Senators and Governors from neighboring southern states (such as Texas Governor and soon-to-be President George W. Bush), federal appointees such as Education Secretary and Mississippi African-American Rod Paige, and RNC leaders such as Mississippian Haley Barbour. While not as active as county Democratic organizations, the county organizations and their affiliates (such as the Republican Women's Federation) do meet with candidates seeking the party nomination for state and local offices, and have hosted fundraisers (speakers have recently included state auditor Phil Bryant, 3rd district congressman Chip Pickering, and U.S. Labor Secretary Elaine Chao). 


\section{Grassroots Party Activists, 2001 and 1991}

\section{Social and Demographic Characteristics of Activists}

Both parties' activists have a higher socioeconomic status compared to the general population, a timeless characteristic shared by party and public officials across the nation, though Democrats are somewhat closer than Republicans to the population's social class. In a state where as late as 1990 only 15 percent of adults over 25 years of age were college graduates, 55 percent of Democratic activists and 65 percent of Republicans in 2001 were college graduates or held graduate degrees, percentages only 4 percent higher for both parties than in 1991 (Shaffer and Breaux 1995). Nearly half of Democratic county chairs held graduate degrees, and Republican county chairs were also somewhat better educated than county committee members (Table 2). Both parties' activists were also more affluent than the state population with 43 percent of Democratic activists and 68 percent of Republicans reporting annual family incomes that exceeded $\$ 50,000$. The proportion of GOP activists who reported incomes exceeding $\$ 75,000$ was over twice that of the Democrats, a concern for Republican Party officials purporting to best represent the average Mississippian whose median household income in 1997 was estimated to be only $\$ 28,527$. Democratic county chairs have somewhat higher incomes than committee members, but few differences existed between Republican chairs and members.

Democratic activists are also more representative than Republicans of the general population in terms of critical gender and race characteristics, though both parties face problems in these areas. Seventy percent of Republican county chairs and committee members are men, and while this overrepresentation of men was most evident ten years ago among the chairs, the increased presence of men among committee members has diminished the presence of women even among these less important activist positions. As existed ten years ago, Democrats are evenly split between men and women in their county committee memberships, but over three-fourths of the county chairs are men. Republicans continue to be a nearly all-white party with 98 percent of committee members and all of the county chairs who responded to our survey being white, a situation that while reflecting the party's weakness among the general African-American population underscores the GOP's Herculean challenge of building a more biracial party. Democratic activists are evenly split between whites and blacks, a situation that mirrors the situation among party identifiers in the general populace. However, the dramatic 13 percentage point increase in the African-American presence among Democratic Party activists who comprised only 33 percent of party activists ten years ago may also reflect the problem of white flight. Twenty 
Table 2. Demographic Characteristics of Mississippi Party Activists

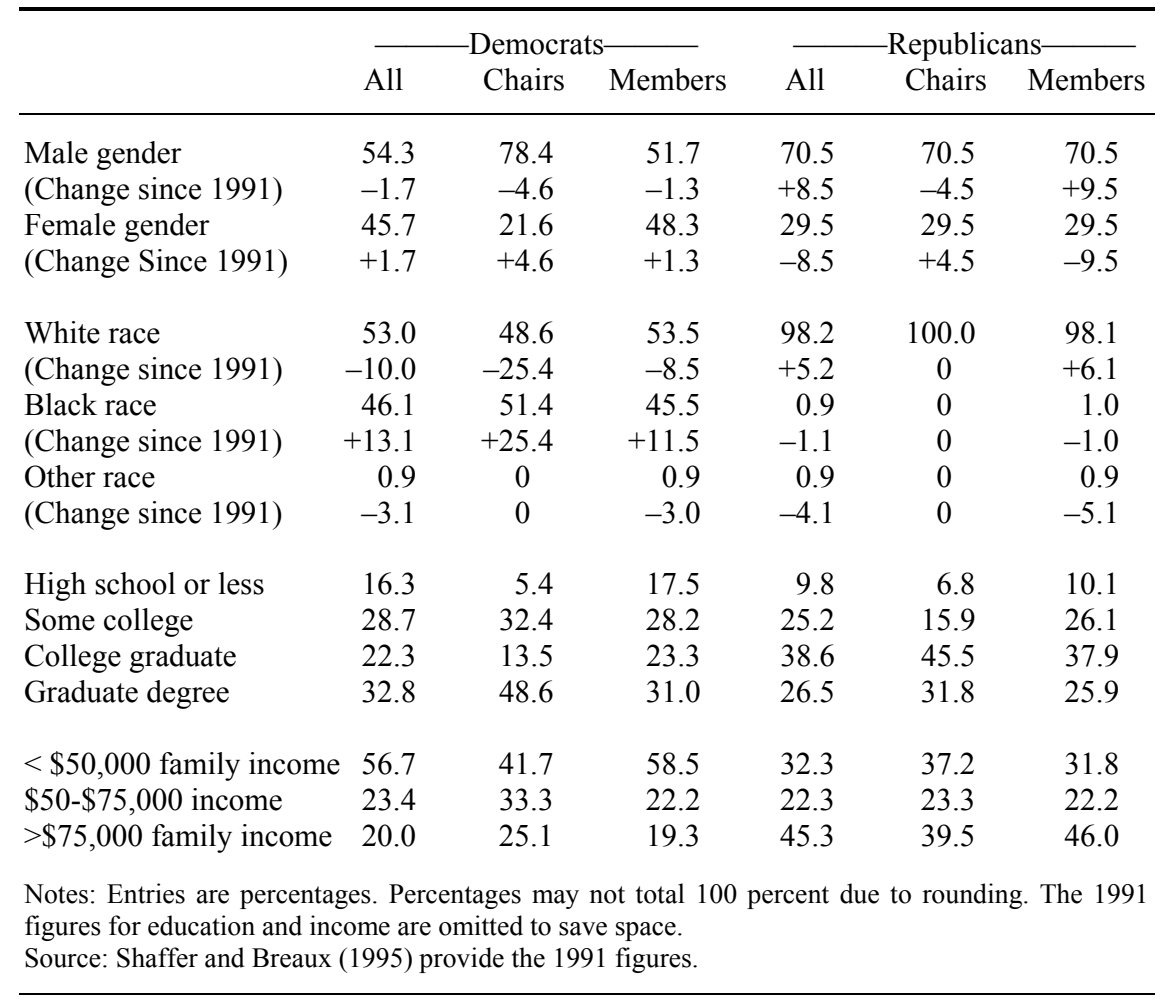

years ago a plurality of average white Mississippians reported Democratic Party identifications, but beginning in 1992 a plurality of whites in the general population began calling themselves Republicans (Shaffer 2001).

Both of the parties reflect the state population's overwhelmingly Protestant religious affiliation, but county chairs are particularly Protestant. Whereas 91 percent of Democratic committee members and 93 percent of Republican members are Protestants, an even higher 95 percent of Democratic chairs and 98 percent of Republican leaders are Protestant. Less than one percent of activists were nonbelievers and only one Jew (a Democrat) was in the sample. Activists in both parties also report a high level of church attendance with 72 percent of Democrats and 67 percent of Republicans claiming to attend church at least once a week. Seventy five percent of both parties' activists believe that religion provides a great deal of guidance in their daily lives. And while 73 percent of both parties' activists admit to 
being "Born Again Christians," 51 percent of Republicans feel that they are close or very close toward Christian Right groups, compared to only 38 percent of Democrats (data not shown).

On the other hand, both parties face a growing geriatric problem, reflected in the difficulty of attracting younger adults to their organizations. In 1991 only 15 percent of Democratic activists and 17 percent of Republican activists were under 40, but ten years later these percentages dropped further to 7 percent of Democrats and 11 percent of Republicans being under 40 . Meanwhile, those 70 and older comprised 21 percent of the ranks of Democratic activists and 27 percent of Republicans, up from only 13 percent of Democrats and 14 percent of Republicans ten years earlier (data not shown). Clearly, both parties need to open up more to the younger generation, perhaps by promoting their College Democrats and College Republicans chapters.

Both parties' activists hail from families that exhibited some political activity, with 68 percent of Democratic county chairs claiming that their parents or relatives were active beyond voting, compared to 50 percent of GOP chairs and 48 percent of both parties' committee members. About 85 percent of Democratic activists had parents with Democratic Party affiliations, compared to only about half of Republican activists, as expected in a historically one-party Democratic state. Republican chairs were more likely to have parents with Republican identifications than were GOP committee members. Forty-three percent of GOP chairs claimed that their father was Republican and 48 percent claimed that their mother was Republican, compared to only 30 percent of GOP committee members claiming a Republican father and 28 percent claiming a Republican mother (data not shown).

Democrats are significantly more active than Republicans in such politically critical interest groups as teachers' organizations, labor unions, and civil rights groups. Forty seven percent of Democrats (chairs and members combined) compared to only 13 percent of Republicans reported that they were "very" or "somewhat" active in teachers" organizations. Comparable levels of activity in labor unions were reported by 22 percent of Democrats and only 3 percent of Republicans. Similarly, 47 percent of Democrats and only 3 percent of Republicans reported being active in civil rights groups. Democrats were also more active in such "liberal" causes as women's rights and environmental groups. Republicans were somewhat more active in a "conservative" cause, the anti-abortion movement, where 18 percent of Republicans and 9 percent of Democrats reported being somewhat or very active. Both parties' activists were equally active in business/ professional organizations, civic organizations, and church groups. 


\section{Recruitment and Involvement}

Mississippi party activists are basically self-starters who received some encouragement from family and friends. When asked who urged them to first become active in party politics, 68 percent of GOP chairs, 64 percent of Democratic chairs, 60 percent of Republican committee members, and 53 percent of Democratic members said that a major consideration was that they decided to participate "pretty much on my own." Friends and family elicited the second highest level of support, ranging from 33 percent of GOP committee members and 38 percent of Democratic members saying they were a major consideration to 40 percent of GOP chairs and 47 percent of Democratic chairs. Only about 25 percent of party activists cited encouragement by party officials, and candidates or elected officials were around 10 percent (data not shown).

When asked who had urged them to seek their current party positions, a similar pattern emerges. Deciding to run by themselves was cited as a major consideration by 50 percent of Democratic chairs and 45 percent of the other three groups of activists. Chairs and committee members differ regarding individual sources of support, as friends and family and a party official were more important to chairs than to committee members. Fifty five percent of Democratic chairs and 57 percent of Republican chairs cited friends or family as a major consideration for seeking their current party position, compared to only 35 percent of Democratic members and 29 percent of GOP members. Similarly, a party official was a major consideration for 52 percent of Democratic chairs and 41 percent of Republican chairs, compared to only 30 percent for Republican members and 24 percent for Democratic members. Less than 15 percent of activists cited candidates or elected officials as a major consideration in their decision to seek their current party position (data not shown).

Regarding motivations for seeking one's current party positions, as found in 1991 candidate support and purposive motivations were especially important to party activists. Over 90 percent of each of the four groups of party activists said they had sought their current party position to support a candidate they believed in. Such purposive motivations as a concern with public issues, and viewing campaign and party work as a way of influencing politics and government were also top motivations of all groups of activists (Table 3). Purposive motivations were more important to county chairs than to committee members, and were somewhat more important to Republicans than to Democrats. Solidarity motivations such as being strongly attached to one's political party, sharing friendships with party workers, and enjoying the fun and excitement of campaigns were also important motivations for party activists, were generally more important to chairs than to committee 
Table 3. Motivations for Seeking One's Current Party Position, 2001

\begin{tabular}{lcccc}
\hline $\begin{array}{l}\text { Very or Somewhat Important in } \\
\text { Decision to Seek Current Party Position }\end{array}$ & \multicolumn{2}{c}{$\begin{array}{c}\text { Democratic } \\
\text { Chairs }\end{array}$} & $\begin{array}{c}\text { Rembers } \\
\text { Chairs }\end{array}$ & Members \\
\hline Candidate friendship & 33.3 & 43.1 & 27.3 & 38.3 \\
Political party official friendship & 51.5 & 53.0 & 50.0 & 56.0 \\
Political work is a way of life & 74.3 & $65.3^{*}$ & 77.3 & $62.6^{*}$ \\
Strongly attached to my political party & 88.9 & $75.9^{*}$ & 88.4 & 80.8 \\
Friendships with party workers & 91.4 & $72.1^{*}$ & 72.7 & $59.6^{*}$ \\
Family=s involvement in party politics & 50.0 & 47.0 & 38.7 & 34.3 \\
Like the fun and excitement of campaigns & 71.4 & 62.9 & 59.1 & 51.7 \\
Build a personal position in politics & 38.9 & 28.4 & 23.3 & 17.8 \\
Campaign work influences politics/gov't & 88.8 & $73.3 *$ & 95.5 & $82.7^{*}$ \\
Party work influences politics and gov't & 94.4 & $74.9 *$ & 97.7 & $84.2^{*}$ \\
Closeness to people doing important things & 63.9 & 57.1 & 47.7 & 45.6 \\
Party work helps business contacts & 27.7 & 28.3 & 13.9 & 16.4 \\
Party helps sense of community obligation & 86.1 & 80.1 & 86.4 & $73.0^{*}$ \\
Party helps recognition in community & 38.9 & 40.2 & 43.2 & $27.0^{*}$ \\
My concern with public issues & 94.3 & $88.7 *$ & 95.4 & 91.5 \\
Support candidates I believe in & 94.4 & 90.7 & 93.2 & 92.7 \\
Notes: Entries are percentages of respondents who answered somewhat important or very important. \\
*Indicates Chi-square differences between a party's chairs and members are statistically significant \\
at .05 level.
\end{tabular}

members, and were somewhat more relevant to Democrats than to Republicans. Other motivations cited as very or somewhat important by a majority of activists were a sense of community obligation, viewing politics as a way of life, and friendship with a political party official. Material incentives, such as making business contacts and building a personal position in politics, were much less important to activists of both parties.

Generally, few differences exist between the two parties in terms of previous party and public positions held. Over eighty percent had never held appointed or elected public office, and over seventy percent had never run for elected public office. About seventy percent of activists in both parties had previously held only one or two party or appointed public positions. The historic electoral dominance of the Democratic Party may help explain two areas in which the parties did differ. Thirty two percent of Republicans had previously held a party position, compared to only 18 percent of Democrats, suggesting some difficulty of the GOP in attracting new activists to these political positions. Fully 63 percent of Republicans indicated that they did not expect to run for public office in the future, compared to only 49 percent of Democrats (data not shown). 
In amateur-professionalism stylistic orientations, as in the 1991 Grassroots Activists study, Democrats remain a more professional party dedicated to winning elections, while Republicans are more "purist" in stressing ideological issues over victory in November. Majorities of Democrats believe that party workers should support the party candidate even if they disagree with them, that party unity is more important than a full discussion of divisive issues, and that broad electoral appeal is more important than a consistent ideology, while majorities of Republicans disagree with those statements (see Table 4). To the extent that differences exist between county chairs and

Table 4. Amateur-Professional Orientations, 2001

\begin{tabular}{|c|c|c|c|c|}
\hline & \multicolumn{2}{|c|}{ Democratic } & \multicolumn{2}{|c|}{ Republican } \\
\hline & Chairs & Members & Chairs & Members \\
\hline $\begin{array}{l}\text { Good party workers support any } \\
\text { candidate nominated by the party } \\
\text { even if they basically disagree } \\
\text { with the candidate. }\end{array}$ & 88.5 & $56.1^{*}$ & 40.9 & 40.5 \\
\hline $\begin{array}{l}\text { Party organization and unity } \\
\text { are more important than free } \\
\text { and total discussion of issues } \\
\text { which may divide the party. }\end{array}$ & 55.6 & 56.2 & 40.9 & 37.7 \\
\hline $\begin{array}{l}\text { A political party should be } \\
\text { more concerned with issues } \\
\text { than winning elections. }\end{array}$ & 60.0 & $79.8^{*}$ & 65.9 & 68.2 \\
\hline $\begin{array}{l}\text { Controversial positions } \\
\text { should be avoided in party } \\
\text { platform to insure party unity. }\end{array}$ & 41.2 & 54.7 & 45.4 & 43.5 \\
\hline $\begin{array}{l}\text { Broad electoral appeal is } \\
\text { more important than a } \\
\text { consistent ideology. }\end{array}$ & 53.3 & 51.7 & 34.9 & 34.8 \\
\hline $\begin{array}{l}\text { Good party workers should } \\
\text { remain officially and } \\
\text { unofficially neutral in primary } \\
\text { contests even when they have a } \\
\text { personal preference. }\end{array}$ & 88.9 & $70.4 *$ & 68.2 & $47.6^{*}$ \\
\hline $\begin{array}{l}\text { Notes: Entries are percentages of res } \\
\text { *Indicates that Chi-square difference } \\
\text { significant at the } .05 \text { level. }\end{array}$ & $\begin{array}{l}\text { s who ag } \\
\text { en chairs }\end{array}$ & $\begin{array}{l}\text { or strongly a } \\
\text { members for }\end{array}$ & $\begin{array}{l}\text { d. } \\
\text { ven party }\end{array}$ & statistically \\
\hline
\end{tabular}


committee members, chairs are more professional while members are more amateuristic. Democratic and Republican chairs are more likely to endorse remaining neutral in primary contests even if they have a personal preference than are committee members. While few differences exist in the GOP, Democratic chairs are more likely than members to argue that party workers should support the party nominee and less likely to assert that a party should be more concerned over issues than with winning elections.

\section{Attitudes of Activists}

The average Republican falls midway between the somewhat conservative and very conservative self-identification categories, while the average Democrat falls between the moderate and somewhat liberal categories. Party differences exist on a wide variety of social welfare, race, women's issues, social issues, and defense spending issues with Republicans being more conservative than Democrats on all except one issue item (see Table 5). The greatest inter-party differences emerge on the issues of gun control, school vouchers, and reducing federal spending on health and education, where Democrats are to the ideological left of the issue item's midpoint and Republicans are to the right. The parties are also on opposing sides of the item midpoints on the issues of aid to racial minorities, managed health care, government aid to women, gay rights, abortion, and environmental spending. On some issues, only one party stakes out an ideologically distinct position, while the other party takes a position closer to the issue item's midpoint. Republicans are more conservative on a flat tax and Washington guaranteeing jobs and a good living standard than are the middle-of-the-road Democrats, while Democrats are more liberal on health care and public school spending compared to the centrist Republicans (on these popular programs). Both parties are to the right of center on affirmative action, welfare spending, death penalty, school prayer, defense spending, and crime spending, and both parties are to the left of center on social security and an equal role for women. Even on these issues where both parties share the same side of the ideological spectrum, in a relative sense (except on crime spending) Republicans are more conservative than are Democrats.

Democrats face a continuing challenge in holding together their biracial and ideologically diverse coalition. While the average white Democrat selfidentifies as a moderate, the average black Democrat is closer to the "somewhat liberal" category. Indeed, on every issue except three, African-American Democrats are more liberal than are white Democrats, suggesting that a Democratic candidate who is a centrist may run the risk of alienating some black Democratic activists who may then sit out the election. Democrats also face possible electoral dissatisfaction among white Democrats, who are 
Table 5. Policy Views of Mississippi Party Activists

\begin{tabular}{lcccccc}
\hline & & & White & Black & Chg 1991-2001 \\
Issue & Reps & Dems & Dems & Dems & Rep & Dem \\
\hline Health and education cuts & 3.02 & 1.87 & 2.07 & 1.65 & +.01 & +.20 \\
Regulate managed health care & 3.12 & 2.20 & 2.42 & 1.96 & NA & NA \\
Environmental spending & 2.24 & 1.60 & 1.65 & 1.53 & NA & NA \\
Public schools spending & 1.99 & 1.25 & 1.43 & 1.06 & NA & NA \\
Social security spending & 1.88 & 1.32 & 1.43 & 1.20 & NA & NA \\
Health care spending & 1.95 & 1.21 & 1.34 & 1.07 & NA & NA \\
Welfare programs spending & 2.77 & 2.13 & 2.35 & 1.84 & NA & NA \\
Vouchers for private schools & 2.96 & 1.69 & 1.87 & 1.47 & NA & NA \\
Flat tax & 3.14 & 2.59 & 2.51 & 2.67 & NA & NA \\
Gov't provide jobs/good living & 3.43 & 2.50 & 2.88 & 2.07 & -.21 & -.10 \\
Feds aid black minorities & 2.85 & 1.88 & 2.35 & 1.88 & +.04 & +.25 \\
Affirmative action & 3.64 & 2.76 & 3.29 & 2.13 & -.07 & +.03 \\
Equal role for women & 1.86 & 1.60 & 1.67 & 1.55 & +.21 & +.24 \\
Feds aid women & 2.76 & 1.86 & 2.10 & 1.60 & -.35 & -.01 \\
Abortion & 3.05 & 2.20 & 2.41 & 1.98 & -.27 & +.09 \\
Public school prayer & 3.53 & 3.27 & 3.09 & 3.46 & -.01 & +.09 \\
Death penalty for murder & 3.19 & 2.56 & 2.82 & 2.25 & NA & NA \\
Crime spending & 2.43 & 2.60 & 2.51 & 2.69 & NA & NA \\
Handgun control & 3.22 & 1.89 & 2.23 & 1.51 & NA & NA \\
Gay rights in employment & 3.22 & 2.36 & 2.64 & 2.04 & NA & NA \\
Defense spending & 2.84 & 2.35 & 2.41 & 2.31 & NA & NA \\
Ideology self-identification & 4.45 & 2.69 & 3.01 & 2.34 & -.26 & +.22 \\
Note: Entries are mean scores. Issue items are recorded to range from liberal (low) scores to con- & \\
servative (high) scores. Most item scores range from 1 to 4 except for the seven spending items that \\
range from 1 to 3, and ideological self-identification that ranges from 1 to 5. & & \\
NA indicates the question was not asked in 1991. & & & & \\
\hline
\end{tabular}

generally located ideologically between Republicans and black Democrats. Indeed, white Democrats are ideologically closer to Republicans on the volatile issues of affirmative action and the death penalty than they are to African-American Democrats. On most bread-and-butter issues such as health care, education spending, the environment, and school vouchers, however, white Democrats are closer to their African-American party colleagues than they are to Republicans.

Activists in both parties may face the challenge of moving too far to their national parties' ideological homes, given the relatively more centrist views of average Mississippians. Over the past ten years, the average Republican activist has become somewhat more conservative in ideological self-identification, while the average Democratic activist has become somewhat more liberal (Table 5). While little change has occurred on most issues, 
Republicans have become more conservative since 1991 on abortion, federal provision of jobs and a good living standard, and federal aid to women, while Democrats have become more liberal on opposing cuts to health and education, federal aid to African-Americans, and an equal role for women.

Democrats relative to Republicans face a significantly greater problem of retaining their party activists' loyalties in federal elections than in state politics. In state politics, fully 82 percent of Democrats considered their party identifications as Strong Democrats, roughly comparable to the 86 percent of Republicans who considered themselves as Strong Republicans. In national politics, Republicans were significantly more partisan than were Democrats, and chairs of both parties were generally more partisan than were committee members. Among Republicans, 98 percent of chairs and 94 percent of members were Strong Republicans in national politics, compared to only 78 percent of Democratic chairs and 73 percent of Democratic members who were Strong Democrats. In reported presidential votes in the last two elections, Republicans backed their presidential candidate at least 95 percent of the time. Only Democratic chairs reached a similar level of party loyalty with 94 percent voting for Clinton and 97 percent for Gore. However, only 86 percent of Democratic committee members backed Clinton in 1996 and only 81 percent voted for Gore in 2000 (data not shown).

Party switching is more evident in the Republican Party, as expected in a historically Democratic state. Twenty six percent of Republicans admit to having at one time been affiliated with a different party, compared to only 5 percent of Democrats. Ninety percent of these party switching Republicans used to be Democrats. Switchers were most likely to become Republican in presidential election years containing popular GOP presidential candidates or during the presidency of a popular Republican president. The more conservative views of the GOP presidential candidates were clearly more appealing than the more liberal views of national Democrats, as 86 percent of Republican party switchers claimed that they switched parties because the GOP had the right stand on issues, while 10 percent said that the Republicans had the more appealing candidates. Switching for reasons of personal advancement, superior party organization, and encouragement by friends and relations was very uncommon (data not shown).

\section{Activity Patterns of Grassroots Activists}

Both parties are active in recruiting candidates for office, as they both seek out people to run for office, and are sought out by those interested in running. County chairs are particularly active in candidate recruitment efforts, as 90 percent of chairs say that they have at one time suggested that someone run for office, and 77 percent say that candidates have talked with 
them before announcing for office. Grassroots activists are also active in party work at the county level and in political campaigns, as we shall soon detail. However, grassroots party activism takes place in an environment where local activists receive little guidance from or even communications with higher level party officials. County chairs as well as county executive committee members report little communication with party officials outside of their county. Strong majorities of both chairs and members in both parties indicate that they have seldom or never communicated with the state party chair, state executive committee members, national committee members, or national government officials (though Democratic chairs reported greater contact with their state executive committee than did Republicans). Contact with local and state government officials is somewhat greater, as over twothirds of activists report that they often or very often communicate with local officials, and over one-third report similar levels of communication with state government officials (data not shown).

A majority of Democratic and Republican chairs and committee members claim that as a responsibility of their current party position they perform thirteen of the fourteen activities asked about. Participating in party meetings, and contacting voters was mentioned by over 80 percent of each of these four groups of activists - chairs and committee members of the two parties (Table 6). County party organizational work, recruiting and organizing workers, contacting new voters, getting people registered to vote, public relations, and increasing people's political information was mentioned by over 70 percent of each group. Recruiting candidates for local office, policy formulation, and campaigning were mentioned by well over 60 percent of the activists. Raising money was reported as an important activity by Republican and particularly Democratic chairs, but by only about half of both parties' committee members. Majorities of both parties' chairs and committee members reported other nominating activities as important responsibilities, while helping develop a party website was mentioned by only about onethird of grassroots activists. As discovered in the 1991 Grassroots Activists study, county chairs are generally more active than are committee members.

Democrats have especially become more likely to report performing these important party activities in their current party roles relative to ten years ago, suggesting some effort to revitalize their party to meet the growing GOP threat. On the thirteen items also asked ten years ago, Democratic county chairs were more active in 2001 than in 1991 on eleven items, and committee members were more active on all thirteen items (Shaffer and Breaux 1995). Republicans had a more mixed record, with both chairs and committee members reporting higher activity in 2001 than in 1991 on seven items (Specific items differed for the two groups). The increased Democratic activism translated into Democratic chairs reporting more activism than 
Table 6. Recent Campaign Activities and Important Party Activities Performed

\begin{tabular}{lcccc}
\hline \multirow{2}{*}{$\begin{array}{l}\text { Activities Done in } \\
\text { Recent Campaigns }\end{array}$} & \multicolumn{2}{c}{ Democratic } & \multicolumn{2}{c}{ Republican } \\
& Chairs & Members & Chairs & Members \\
\hline Organize door-to-door canvassing & 43.2 & 31.3 & 25.0 & 21.1 \\
Organized campaign events & 62.2 & 30.4 & 59.1 & 35.2 \\
Arranged fund-raising activity & 54.1 & 22.6 & 43.2 & 29.9 \\
Sent mailings to voters & 40.5 & 22.9 & 50.0 & 38.5 \\
Distributed campaign literature & 81.1 & 66.3 & 77.3 & 69.4 \\
Organized telephone campaigns & 48.6 & 32.2 & 38.6 & 32.5 \\
Purchased billboard space & 10.8 & 4.2 & 2.3 & 4.8 \\
Distributed posters or lawn signs & 31.1 & 61.4 & 90.9 & 74.4 \\
Contributed money to campaigns & 78.4 & 49.4 & 88.6 & 76.1 \\
Conducted voter registration drive(s) & 51.4 & 33.4 & 31.8 & 11.7 \\
Utilized public opinion surveys & 10.8 & 8.1 & 9.1 & 5.7 \\
Dealt with campaign media & 40.5 & 16.0 & 50.0 & 19.6 \\
Helped with campaign website & 5.4 & 2.7 & 6.8 & 2.2 \\
& & & & \\
Important party activity done: & & & & \\
Contacting voters & 97.2 & 84.4 & 84.0 & 85.2 \\
Raising money & 75.0 & 49.7 & 63.6 & 55.5 \\
Getting people to register to vote & 91.6 & 87.3 & 90.7 & 77.7 \\
Campaigning & 91.6 & 69.0 & 79.1 & 71.9 \\
Public relations & 91.7 & 73.5 & 81.9 & 71.9 \\
Contacting new voters & 94.4 & 78.6 & 84.1 & 73.4 \\
Participating in party meetings & 94.4 & 85.5 & 93.2 & 84.3 \\
Recruiting and organizing workers & 88.8 & 73.2 & 90.7 & 69.7 \\
County party organizational work & 94.2 & 79.2 & 85.4 & 78.3 \\
Increasing other's political information & 94.5 & 79.1 & 90.7 & 78.4 \\
Policy formulation & 86.1 & 63.9 & 79.5 & 63.4 \\
Getting candidates for local office & 86.1 & 68.9 & 81.3 & 71.0 \\
Other nominating activities & 67.6 & 55.5 & 51.1 & 52.0 \\
Helping develop a party website & 32.4 & 31.3 & 39.5 & 21.2 \\
Notes: Entries are percentages. Important party activities combines “very” & and “somewhat.” \\
\hline & & & & \\
\hline
\end{tabular}

GOP chairs on twelve of fourteen items, and into Democratic committee members being more active than Republicans on ten of the items, though the magnitude of party differences was often modest.

Focusing on election campaigns, Democrats appeared to specialize more in local elections while Republicans focused more on national elections, a reasonable reflection of Republican electoral successes in presidential and congressional elections over the last decade and persistent Democratic dominance in many local races. The leadership role of county chairs 
was quite evident in both parties, as both Democratic and Republican county chairs reported more activity in local, state, and national elections than did committee members. For instance, seventy six percent of Democratic chairs and 64 percent of Republican chairs claimed to be very active in local elections, compared to 63 percent of Democratic committee members and 47 percent of Republican committee members. In national elections, 75 percent of Republican chairs and 49 percent of Democratic chairs claimed to be very active, compared to only 48 percent of GOP members and 38 percent of Democratic members. In state elections, 73 percent of Republican chairs and 57 percent of Democratic chairs were very active, compared to 50 percent of both parties' committee members (data not shown).

Turning to specific campaign acts in recent campaigns, the chairs of both parties were more likely to perform twelve of thirteen activities than were that party's committee members. Majorities of all four groups of activists distributed campaign literature, and majorities of three of the groups contributed campaign money and distributed posters or lawn signs (Table 6). Majorities of Democratic and Republican chairs organized campaign events, though fewer committee members did. A majority of Republican county chairs sent mailings to voters and reported dealing with campaign media, while a majority of Democratic chairs conducted voter registration drives and arranged fund-raising activities. Fewer activists organized door-to-door canvassing or telephone campaigns, purchased billboard space, relied on public opinion surveys, or helped with a campaign website.

As with party activities associated with their organization position, Democrats exhibited somewhat greater campaign activity over time than did Republicans. On the twelve items also asked in the 1991 Grassroots Activists study, Democratic committee members were more active on eleven of them in 2001 than ten years ago, while Democratic chairs were more active in 2001 on nine of them. Republicans showed little consistent change over time with chairs being more active recently on only four items and committee members being more active in 2001 on six items (Shaffer and Breaux 1995).

\section{Party Strength and Factionalism}

Both parties believe that they are responding to the heightened competition offered by a true, two-party system. Forty seven percent of Democratic activists and 79 percent of Republicans believe that the overall county party organization has become stronger in the last ten years, while only 30 percent of Democrats and 7 percent of Republicans believe that it has become weaker. Similar patterns emerge for the campaign effectiveness of the county parties. Regarding county party fund-raising ability, candidate 
recruitment activity, efforts to develop workers' organizational skills, the use of media, the use of computer technology, and the party's strength among voters, strong majorities of both parties' activists believe that the county party has either become "somewhat" stronger or that little change has occurred. The least change is perceived in public opinion polling, where 49 percent of Democrats and 64 percent of Republicans see no real change over time (data not shown).

Factionalism is perceived to be a greater problem among Democrats than among Republicans. The degree of factionalism is believed to be very high or moderately high within the state party by 70 percent of Democrats and only 33 percent of Republicans. At the county level, 52 percent of Democrats and only 25 percent of Republicans perceived a similar high level of intra-party factionalism. Democrats perceive more intra-party factionalism than do Republicans because of different ideological viewpoints, differences between long-time residents and newcomers, tax issue divisions, abortion differences, racial issue divisions, and disagreements over government spending. Regional and urban-rural divisions were evident within both parties with 48 percent of activists perceiving a great deal or a fair amount of intra-party differences between regions, and 52 percent perceiving such differences between urban and rural areas (data not shown).

\section{Conclusion}

Mississippi Republicans are a conservative party that has been becoming even more conservative on issues such as abortion, public jobs, and aid to women. An essentially higher income, middle aged, and white male organization, it has become even whiter, more male, and older over the last decade, with many of its activists preferring a more purist orientation and tending to think of themselves as national Republicans.

Democrats are a truly biracial party with equal numbers of men and women and a more middle class background. Their more professional orientation is geared towards winning elections rather than fighting for ideological purity. Democratic county organizations have become increasingly active over the last decade to meet the growing GOP challenge, particularly in electoral campaigns.

Democratic inclusiveness, however, challenges the party's cohesiveness, as reflected in factionalism on issues. African-American Democrats are more liberal than are whites, who are essentially centrist on many issues. Indeed, the views of white Democrats are closer to the GOP on such emotional issues as affirmative action and the death penalty, than they are to their black colleagues, although white and black Democrats share common economic interests. Furthermore, with the influx of more African Americans 
into the party over the last decade, Democrats appear to be shifting somewhat to the left. Finally, while activism in teachers, labor, and civil rights groups can provide the party support in elections, association with such groups as well as environmentalists and feminists may make it easier for the GOP to tag Democrats as the "liberals."

\section{REFERENCES}

Breaux, David, Stephen Shaffer, and Thomas Wilson. 1997. Mississippi. In State Party Profiles: A 50-State Guide to Development, Organization, and Resources, eds. Andrew M. Appleton and Daniel S. Ward. Washington DC: Congressional Quarterly Inc.

Key, V.O. 1949. Southern Politics in State and Nation. New York: Knopf.

Secretary of State of Mississippi. 1993, 1997. Mississippi Official and Statistical Register, 1992-1996, 1996-2000.

Shaffer, Stephen D. 1991. Mississippi: Electoral Conflict in a Nationalized State. In The 1988 Presidential Election in the South, eds. Laurence W. Moreland, Robert P. Steed, and Tod A. Baker. New York: Praeger.

Shaffer, Stephen D. 2001. Political Parties in Modern Mississippi. In Politics in Mississippi, 2nd ed., ed. Joseph B. Parker. Salem, WI: Sheffield Publishing Company.

Shaffer, Stephen D., and David A. Breaux. 1995. Mississippi: The 'True Believers' Challenge the Party of Everyone. In Southern State Party Organizations and Activists, eds. Charles D. Hadley and Lewis Bowman. Westport, CT: Praeger.

Shaffer, Stephen D., Stacie Berry Pierce and Steven A. Kohnke. 2000. Party Realignment in the South: A Multi-Level Analysis. American Review of Politics 21:129-153.

Shaffer, Stephen D., and Byron E. Price. 2002. Mississippi: GOP Blunts Democratic Resurgence. In The 2000 Presidential Election in the South, eds. Robert P. Steed and Larry Moreland. Westport, CT: Praeger.

Shaffer, Stephen D., David E. Sturrock, David A. Breaux, and Bill Minor. 1999. Mississippi: From Pariah to Pacesetter? In Southern Politics in the 1990s, ed. Alexander P. Lamis. Baton Rouge: Louisiana State University Press. 
